\title{
Views on alternative forums for effectively tackling climate change
}

\author{
Mattias Hjerpe and Naghmeh Nasiritousi
}

\section{Linköping University Post Print}

\section{Tweet}

N.B.: When citing this work, cite the original article.

Original Publication:

Mattias Hjerpe and Naghmeh Nasiritousi, Views on alternative forums for effectively tackling climate change, 2015, Nature Climate Change, (5), 9, 864-867.

http://dx.doi.org/10.1038/NCLIMATE2684

Copyright: Nature Publishing Group

http://www.nature.com/

Postprint available at: Linköping University Electronic Press

http://urn.kb.se/resolve?urn=urn:nbn:se:liu:diva-121433 
Title: Policy-makers' and practitioners' views on forums for effectively tackling climate change

Authors

Mattias Hjerpe* and Naghmeh Nasiritousi

Centre for Climate Science and Policy Research, CSPR, and Department of Thematic Studies Environmental Change, Linköping University, Sweden.

\section{First paragraph:}

This year (2015) marks the 21st formal anniversary of the United Nations Framework Convention on Climate Change (UNFCCC) and in December a new climate treaty is expected to be reached. Yet, the UNFCCC has not been successful in setting the world on a path to meet the 2 degree target ${ }^{1}$. Meanwhile, other forums, such as the $\mathbf{G 2 0}$ and subnational forums, have increasingly become sites of climate change initiatives ${ }^{2-6}$. There has, however, to date been no systematic evaluation of what forums climate change policy-makers and practitioners perceive to be needed in order to effectively tackle climate change. Drawing on survey data from two recent UNFCCC Conference of the Parties (COP), we show that there exists an overall preference for state-led, multilateral forums. However, preferences starkly diverge between respondents from different geographical regions and no clear contender to the UNFCCC emerges. Our results highlight difficulties in coordinating global climate policy in a highly fragmented governance landscape.

International efforts to tackle the challenges posed by climate change have in the past two decades centered on multilateral negotiations under the UNFCCC. Several scholars note however that the international negotiations under the UNFCCC have produced diminishing returns over time ${ }^{7}$. This has generated discussions about whether multilateralism should be abandoned in favor of minilateralism ${ }^{8}$, along with suggestions to shift the negotiations to other smaller and more flexible forums ${ }^{9}$. Critics of the current multilateral approach argue that it is too cumbersome, as the decision-making process of the UNFCCC relies on finding consensus among its 195 parties $^{10-11}$. David Victor ${ }^{11}$, for example, has argued that since only a dozen countries emit the majority of the world's greenhouse gas emissions, a club like the Major Economies Forum on Energy and Climate (MEF) would present a good candidate for making progress on climate change. Others, however, maintain that minilateral clubs like the MEF, G8, and the Asia-Pacific Partnership are not necessarily more effective than the UNFCCC, lack the legitimacy of the UN climate process ${ }^{6}$, and do not primarily focus on significantly increasing mitigation ambition ${ }^{5}$.

A related discussion concerns the architecture of climate change governance. Thus far the main efforts to respond to climate change have been state-led, focusing on building a universal regime through a legally binding multilateral agreement in a so-called top-down approach. Proponents of this architecture maintain that a strong, centralized regime is necessary for ensuring effective and fair outcomes $^{12-13}$. Critics, however, argue that a bottom-up approach, favoring more national and nonstate initiatives, would provide a more effective response ${ }^{14-16}$. A range of sub-national and transnational initiatives, such as the C40 network of major cities and the Carbon Disclosure Project, have shown that other actors can take ambitious steps when national governments resist strong targets and timetables ${ }^{3}$. This, however, increases the fragmentation of climate change governance ${ }^{17}$. Fragmented institutions, in turn, complicate policy coordination ${ }^{18}$ and raise questions about the legitimacy and effectiveness of hybrid governance arrangements ${ }^{19}$. The pledge-and-review system 
emerging since the Copenhagen Accord has moved climate governance towards a bottom-up approach, with implications for the catalytic role of the UNFCCC ${ }^{13}$.

A pertinent question is whether there are other forums than the UNFCCC that could effectively tackle climate change? This study presents results from 922 valid responses from the International Negotiations Survey distributed to participants at two consecutive UNFCCC COPs (2013 and 2014). The question analyzed reads: "What other forums outside the UNFCCC are, in your view, important for effectively tackling climate change?" (see Methods for details). This data is presented to examine how a range of climate change policy-makers and practitioners perceive the importance of forums outside the UNFCCC in terms of scales (Table 1), issue-areas (Table 2) and whether the forums are led by governments or other actors (Supplementary Table 1). These results are compared across six world geographical regions and between governmental and non-governmental (NGO) respondents.

The data show a wide spread in responses, with forums spanning from the global to local levels. The G20 (14\%), the MEF (5\%), the UN Convention on Biological diversity (5\%) and the Montreal Protocol (4\%) were the four most frequently mentioned individual forums. The low figures suggest that climate change policy-makers and practitioners do not see any given alternative to the UNFCCC. Instead survey respondents state a wide range of institutions and initiatives, such as climate clubs, transnational governance initiatives, public-private partnerships and other alternative climate governance instruments, in line with the fragmented picture of climate governance as portrayed in the literature ${ }^{2,17,20}$. The breadth of answers shows that there exists no lack of innovation in governance arrangements to respond to climate change, albeit with low agreement among policy-makers and practitioners on which of these are important for effectively tackling climate change.

Overall, both governmental and NGO respondents identify other multilateral forums (defined here as international organizations with near universal membership) as important for tackling climate change, over minilateral forums (defined here as groupings with select state membership) and forums organized at lower administrative levels (Table 1). The preferences for multilateralism in general and UN-led multilateralism in particular were strongest among government representatives. These preferences were relatively even across geographical regions, with respondents from South and Latin America (S\&L America) standing out for expressing the strongest preferences for multilateral, UN-led forums (66\%).

The preferences for minilateral forums varied more significantly amongst government representatives across geographical regions. Those from Europe and North America express surprisingly strong preferences for minilateral forums - about two thirds of the government respondents from these regions. This indicates a large potential for such forums in these regions. In contrast, the preferences for minilateralism are very weak among government representatives from the other four regions. This finding is expected given the weak role of most of these countries in such minilateral fora, reflecting political power imbalances in such governance arrangements. For example, while several Asian countries have participated in prominent minilateral forums, such as the Asia-Pacific Partnership on Clean Development and Climate, these tend to be initiated and driven by other states ${ }^{21}$.

Interestingly, government representatives' preferences for bilateral ( 2 to $5 \%$ ), national (5 to $13 \%$ ) and most notably local (1 to $10 \%$ ) forums increased dramatically from COP-19 to COP-20. Moreover, the preferences for regional, minilateral and IGO-led forums remained stable while the data suggest a drop in the preferences for UN-led forums (52 to 40\%). Consequently, the data suggests a shift in preferences from the multilateral governance level towards lower administrative levels rather than to governance forums with a more select state membership. 
Overall, NGOs identified national and local forums to a larger extent than government respondents, indicating support for bottom-up approaches (Supplementary Information). Our data suggest relatively stable NGO preferences over time, with the exception of a growing support for minilateral forums from COP-19 to COP-20 (16 to $22 \%$ ).

The data were also categorized according to the forum's primary issue-area. This sheds light on the extent to which respondents view that effective responses to climate change will require action in other topical areas. Besides climate forums, government representatives indicate preferences for economic and environmental forums (Table 2).

Significant differences in the responses on issue-areas are found across geographical regions. The preferences of North American government representatives are stronger for climate (MEF and the Climate and Clean Air Coalition), environment (specifically atmosphere forums, i.e. Montreal protocol) and economic (G20) forums, while preferences for social forums are very low. The preferences of European government representatives are significantly stronger for economic forums (predominantly the OECD) and slightly lower for environmental forums. The preferences of S\&L American government representatives are stronger for climate and social forums (Indigenous peoples forums) and weaker for economic forums. The preferences of Oceanian government representatives are weaker for climate and economic forums but stronger for general forums (notably the Pacific Islands Forum) and atmosphere forums. African and Asian government representatives' views were more similar to the world averages, with the exception that African government representatives' preferences for economic forums were significantly weaker and those for biodiversity forums (UN Convention on Biological Diversity) stronger.

Comparing tables 1 and 2 shows that preferences for minilateral forums noticeably overlap with preferences for economic forums, highlighting the concern that minilateral approaches risk limiting not only membership but also the issues under discussion ${ }^{6,8,22}$.

Supplementary Table 1 examines whether the identified forums are led by states, IGOs, non-state actors or hybrid arrangements (mix of state and non-state actors). Government representatives clearly view other state-led and IGO-led forums outside the UNFCCC as important for effectively tackling climate change. This is most pronounced among North American and European government representatives. In contrast, S\&L American and Asian government representatives indicate weaker preferences for state-led forums. The preferences for state-led forums were unchanged between the years while the preferences for IGO-led forums weakened (54 to 34\%). Interestingly, government representatives across all six geographical regions indicate weak preferences for both non-state-led (19\%) and hybrid (14\%) forums, but the data suggest strengthened preferences for non-state-led forums from $15 \%$ at COP-19 to $21 \%$ at COP-20. This indicates a low, but growing, recognition for nonstate initiatives by state actors. The pattern of identifying state rather than hybrid or non-state forums is unexpectedly most marked among government representatives from North America and Europe. This is puzzling given the often high level of government support for non-state initiatives in these regions.

Unsurprisingly, NGO respondents overall mention non-state forums more often than government representatives. NGO representatives' preferences for non-state-led forums however diverge substantially across geographical regions, which may reflect the uneven pattern of non-state initiatives currently underway ${ }^{3}$. 
We have established that there exists little agreement on which other forums outside the UNFCCC are important for effectively tackling climate change. Moreover, the generally strong support for state-led, multilateral, climate forums among our survey respondents mirrors the UNFCCC's structure in terms of scale, issue-area and actor type. Yet, the multitude of responses indicating other forums as important shows that the UNFCCC is no longer the only show in town.

Notably, our study demonstrates strong preferences among climate change policy-makers for minilateral forums in two out of six world regions, harboring around $40 \%$ of world greenhouse gas emissions. Consequently, there is a large potential for pursuing climate change in minilateral forums dealing with climate change and economic issues in North America and Europe. Even in these regions, however, the results show differences in which types of organizations are deemed most important, with North American respondents highlighting the MEF, and European respondents frequently citing the OECD. Such minilateral forums are not acknowledged by policy-makers in the other four regions, however. Minilateral forums in their current form are therefore unlikely to deliver legitimate global solutions to climate change.

To the extent that we can see trends in our data, government support for minilateral forums has remained stable over the two years measured. Instead, governments appear to express stronger (although still relatively weak) preferences for bilateral, national and local forums and express a growing recognition for non-state initiatives. This could be a reflection of recent developments, with the bilateral US-China climate agreement announced in November 2014 and the growing visibility of non-state initiatives (e.g. those highlighted by the UNFCCC's NAZCA portal23).

The breadth of answers to our survey question map out a highly complex and fragmented climate governance landscape, presenting both opportunities and risks. The potential advantages of the current architecture include the facilitation of learning and building of trust through an increase in interactions between different actors and initiatives ${ }^{14}$. The risk is normative contestation between different governance arrangements that foster competition over cooperation and that risk undermining the work of the UNFCCC ${ }^{21}$. The launch of the NAZCA portal at COP-20 and other efforts to highlight international cooperative initiatives ${ }^{24}$ indicate that the UNFCCC is attempting to take on an umbrella role to provide a framework for coordinating actions in the currently highly fragmented climate governance landscape. Establishing portals alone will, however, not ensure synergies. Future research should therefore focus on how to best combine top-down and bottom-up processes to spur innovative climate policies. Achieving effective coordination of diverse climate initiatives is likely to be a key challenge for the UNFCCC as it is entering its third decade.

Correspondence to: Mattias Hjerpe, mattias.hjerpe@liu.se

\section{Acknowledgements}

We would like to thank David Bastviken, Mathias Fridahl, Björn-Ola Linnér and Heike Schroeder for valuable suggestions on a previous draft, colleagues in the International Negotiations Survey team who assisted in handing out surveys during COP-19 and COP-20, the Swedish Research Council, under grant award No. 421-2011-1862, and Formas, under grant award No. 2011-779. 


\section{Author contributions}

$\mathrm{MH}$ and NN jointly designed the study, developed the methodology, performed the analysis, and wrote the manuscript. The survey data was collected by the International Negotiations team at COP19 and COP-20.

\section{References}

${ }^{1}$ Jordan, A. et al. Going beyond two degrees? The risks and opportunities of alternative options. Climate Policy 13, 751-769, doi:10.1080/14693062.2013.835705, (2013).

${ }^{2}$ Keohane, R. O. \& Victor, D. G. The Regime Complex for Climate Change. Perspectives on Politics 9, 723, doi:10.1017/S1537592710004068, (2011).

${ }^{3}$ Bulkeley, H. et al. Transnational Climate Change Governance. (Cambridge University Press, 2014).

${ }^{4} \mathrm{Kim}, \mathrm{J}$. \& Chung, S.-Y. The role of the $\mathrm{G} 20$ in governing the climate change regime. International Environmental Agreements: Politics, Law and Economics 12, 361-374, doi:10.1007/s10784-0129173-2, (2012).

${ }^{5}$ Weischer, L., Morgan, J. \& Patel, M. Climate clubs: Can small groups of countries make a big difference in addressing climate change? Review of European Community \& International Environmental Law 21(3), 177-192, (2014).

${ }^{6}$ Karlsson-Vinkhuyzen, S. I. \& McGee, J. Legitimacy in an Era of Fragmentation: The Case of Global Climate Governance. Global Environmental Politics 13, 56-78, doi:10.1162/GLEP_a_00183, (2013).

${ }^{7}$ Falkner, R., Stephan, H. \& Vogler, J. International Climate Policy after Copenhagen: Towards a 'Building Blocks' Approach. Global Policy 1, 252-262, doi:10.1111/j.1758-5899.2010.00045.x, (2010).

${ }^{8}$ Eckersley, R. Moving Forward in the Climate Negotiations: Multilateralism or Minilateralism? Global Environmental Politics 12, 24-42, doi:10.1162/GLEP_a_00107, (2012).

${ }^{9}$ Naim, M. Minilateralism: The Magic Number to Get Real International Action. Foreign Policy 173, 135-136, (2009).

${ }^{10}$ Grasso, M. \& Roberts, T. A compromise to break the climate impasse. Nature Climate Change 4, 543-549, (2014).

${ }^{11}$ Victor, D. Plan B for Copenhagen. Nature 461, 342-344, (2009).

${ }^{12}$ Hare, W., Stockwell, C., Flachsland, C. \& Oberthür, S. The architecture of the global climate regime: a top-down perspective. Climate Policy 10, 600-614, doi:10.3763/cpol.2010.0161, (2010). 
${ }^{13}$ Winkler, H. \& Beaumont, J. Fair and effective multilateralism in the post-Copenhagen climate negotiations. Climate Policy 10, 638-654, doi:10.3763/cpol.2010.0130, (2010).

${ }^{14}$ Cole, D. H. Advantages of a polycentric approach to climate change policy. Nature Climate Change 5, 114-118, doi:10.1038/nclimate2490, (2015).

${ }^{15}$ Rayner, S. How to eat an elephant: a bottom-up approach to climate policy. Climate Policy 10, 615621, doi:10.3763/cpol.2010.0138, (2010).

${ }^{16}$ Dai, X. Global regime and national change. Climate Policy 10, 622-637, doi:10.3763/cpol.2010.0146, (2010).

${ }^{17}$ Abbott, K. W. The transnational regime complex for climate change. Environment and Planning C: Government and Policy 30, 571-590 (2012).

${ }^{18}$ Zürn, M. \& Faude, B. Commentary: On Fragmentation, Differentiation, and Coordination. Global Environmental Politics 13, 119-130, doi:10.1162/GLEP_a_00, (2013).

${ }^{19}$ Bäckstrand, K. Accountability of Networked Climate Governance: The Rise of Transnational Climate Partnerships. Global Environmental Politics 8, 74-102, doi:10.1162/glep.2008.8.3.74, (2008).

${ }^{20}$ Biermann, F., Pattberg, P., van Asselt, H., Zelli, F. The fragmentation of global governance achitectures: A framework for analysis. Global Environmental Politics 9, 14-40, (2009).

${ }^{21}$ McGee, J. \& Taplin, R. The Asia-Pacific partnership and market-liberal discourse in global climate governance. International Journal of Law in Context 10, 338-356, doi:10.1017/S1744552314000159, (2014).

${ }^{22}$ Huang, J. A Leadership of Twenty (L20) Within the UNFCCC: Establishing a Legitimate and Effective Regime to Improve Our Climate System. Global Governance: A Review of Multilateralism and International Organizations 15, 435-441, doi:10.5555/ggov.2009.15.4.435, (2009).

${ }^{23}$ http://climateaction.unfccc.int/. Last accessed 12 May 2015.

${ }^{24}$ http://unfccc.int/focus/mitigation/items/7907.php. Last accessed 12 May 2015. 
Table 1: Percentage of all COP19/20 respondents indicating forums operating at different scales and with different terms of membership divided into governmental and NGO representatives.

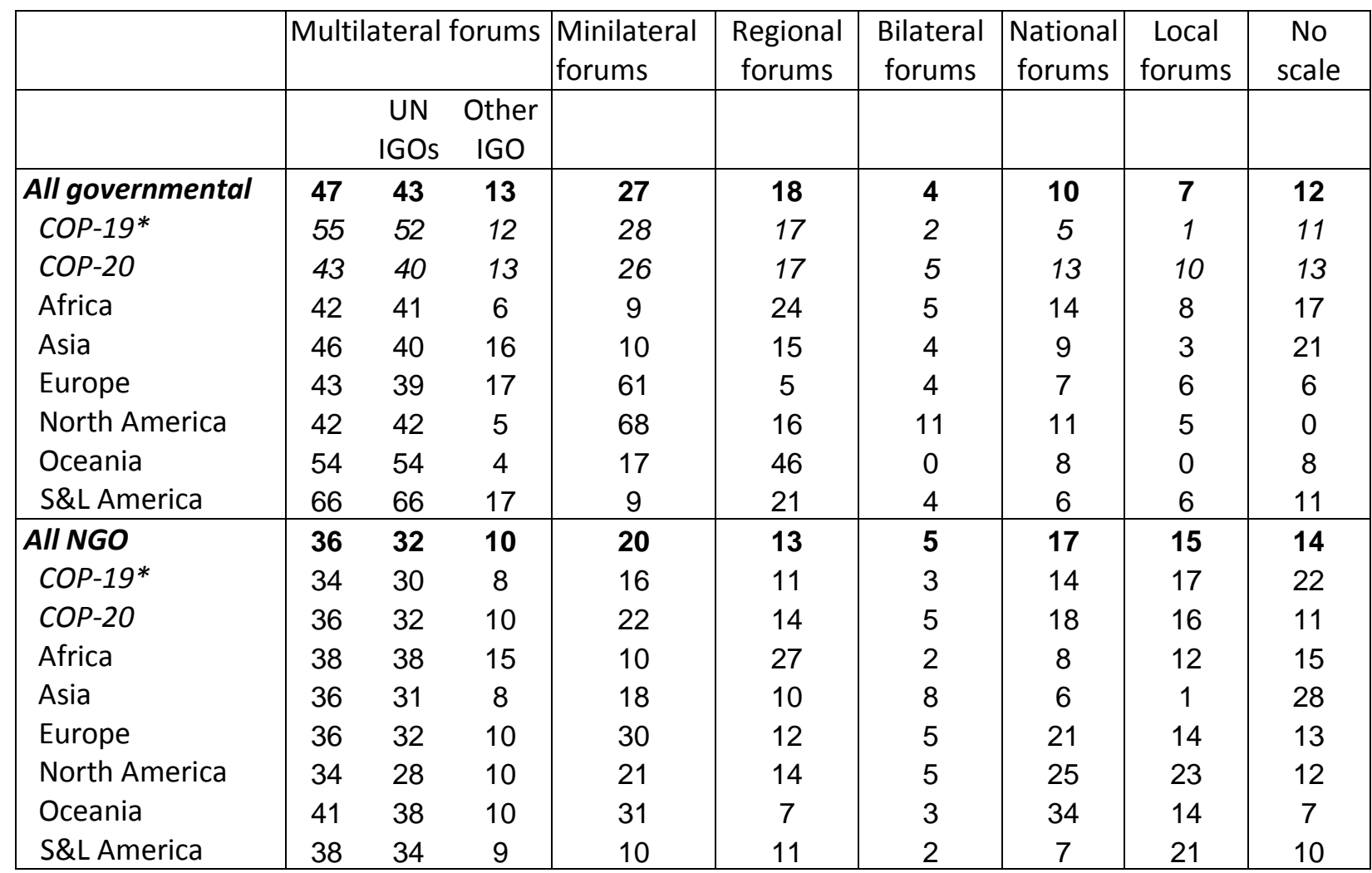

NB! Respondents could indicate several fora and, consequently, the total percentages do not sum up to $100 \%$ (in each row of the table). This also applies to the Multilateral forums column, which means that the sum of the percentages for UN IGOs and Other IGOs do not sum up to the percentage for multilateral forums. * COP-19 values were compensated for variations in sample sizes in world regions using the regional governmental respondent shares of the COP-20 sample. 
Table 2: Percentage of all COP19/20 respondents indicating forums according to their primary issuearea divided into governmental and NGO representatives.

\begin{tabular}{|c|c|c|c|c|c|c|c|c|c|}
\hline & Climate & Envir & nment & & & Economic & Social & Gener & Not \\
\hline & & & $\begin{array}{l}\text { Atmo } \\
\text { spher }\end{array}$ & $\begin{array}{r}\text { Bio- } \\
\text { divers }\end{array}$ & $\begin{array}{l}\text { Other } \\
\text { ronmental } \\
\text { issues }\end{array}$ & & & & \\
\hline All governmental & 37 & 26 & 7 & 6 & 11 & 29 & 14 & 12 & 17 \\
\hline COP-19* & 34 & 29 & 10 & 9 & 14 & 25 & 16 & 15 & 10 \\
\hline COP-20 & 40 & 26 & 6 & 5 & 10 & 31 & 15 & 10 & 20 \\
\hline Africa & 33 & 29 & 2 & 12 & 18 & 13 & 17 & 9 & 19 \\
\hline Asia & 39 & 19 & 4 & 3 & 7 & 28 & 13 & 12 & 25 \\
\hline Europe & 40 & 20 & 7 & 1 & 7 & 50 & 15 & 5 & 8 \\
\hline North America & 58 & 37 & 32 & 5 & 0 & 37 & 0 & 11 & 11 \\
\hline Oceania & 13 & 38 & 21 & 4 & 4 & 17 & 4 & 29 & 17 \\
\hline S\&L America & 49 & 32 & 4 & 11 & 21 & 21 & 23 & 21 & 11 \\
\hline$A / l$ NGO & 33 & 17 & 4 & 6 & 4 & 28 & 23 & 10 & 25 \\
\hline COP-19* & 31 & 17 & 5 & 5 & 2 & 19 & 28 & 7 & 31 \\
\hline$C O P-20$ & 34 & 17 & 3 & 6 & 5 & 30 & 22 & 11 & 24 \\
\hline Africa & 21 & 29 & 0 & 8 & 8 & 17 & 37 & 8 & 27 \\
\hline Asia & 36 & 18 & 0 & 6 & 5 & 25 & 15 & 6 & 20 \\
\hline Europe & 29 & 12 & 5 & 2 & 1 & 36 & 23 & 13 & 26 \\
\hline North America & 31 & 15 & 6 & 3 & 3 & 28 & 19 & 13 & 32 \\
\hline Oceania & 31 & 21 & 3 & 10 & 0 & 41 & 14 & 7 & 24 \\
\hline S\&L America & 48 & 24 & 1 & 13 & 9 & 18 & 31 & 6 & 20 \\
\hline
\end{tabular}

NB! Respondents could indicate several fora and, consequently, the total percentages do not sum up to $100 \%$ (in each row of the table and the overall Environment issue-category). ${ }^{*}$ COP-19 values were compensated for variations in sample sizes in world regions using the regional governmental respondent shares of the COP-20 sample. 


\section{Methods}

Survey methods are increasingly used to examine preferences of, and activities performed by, different actors participating in the COPs of the UNFCCC in situ or by distributing surveys based on the List of Participants ${ }^{25-33}$.

The data used in this study consists of a survey distributed through the International Negotiations Survey (INS) (http://www.internationalnegotiationssurvey.se) to 1500 participants at UNFCCC COP-19 in Warsaw and COP-20 in Lima. The INS has previously been used to study various aspects of climate change, such as leading actors ${ }^{27}$, effective solutions to climate change ${ }^{28}$, NAMAs ${ }^{29}$, preferences for conceptual or proportional historical responsibility ${ }^{30}$, the roles of non-state actors in climate change governance ${ }^{31}$, criticism of the pledge and review system ${ }^{32}$, and expectations on corporate climate action $^{33}$. The surveys were distributed in person at the UNFCCC COP venues, an operating environment that hampers random sampling. Quota sampling was instead used to select a strategic sample of the two most important categories of COP participants: (i) members of party delegations, such as negotiators and representatives of government agencies (henceforth 'governmental'); and (ii) observers, i.e. environmental, development, business and industry, and research and independent NGO representatives (henceforth, 'non-governmental' or NGO). Responses from the small categories Intergovernmental Organizations (IGO) and media representatives have been included in the non-governmental sample.

Roughly $40 \%$ of the 922 valid responses were from governmental (366) and 60\% were from nongovernmental (556) representatives, our sample under-represents governmental respondents in comparison to the composition of the frame population in COP-19 and COP-20, comprising approximately $47 \%$ governmental, $53 \%$ nongovernmental $\left.\right|^{34-35}$. The sample contains less media and intergovernmental representatives than the frame population. In terms of geographical representation (UNFCCC Secretariat unpublished data), the sample overall corresponds well with participation from the six world regions; with a slight over-representation to African Group and Latin American government delegates in comparison to delegates from European and North American countries. Percentages are available from the corresponding author upon request.

The question that is analyzed here reads: "What other forums outside the UNFCCC are, in your view, important for effectively tackling climate change? Please provide examples:". Respondents were asked to indicate in free text which forum or forums they believed to be important for tackling climate change.

Since the UNFCCC is a node for intergovernmental collaboration on climate change and attracts actors that work with climate change issues at different levels $\mathrm{s}^{34-36}$, our sample captures expert views on other forums and provides a starting point for exploring preferences for involving other institutions beyond the UNFCCC to a greater extent in climate change governance. However, given that our survey respondents are participants of a UNFCCC COP, a strong bias in favor of other UNforums in the responses is expected.

Survey responses were first categorized based on types of forums, such as UN-forums, other IGO forums, Climate Clubs and initiatives, Regional forums, National forums, and Local forums. This analysis enriches the current understanding by shedding light on what types of other forums climate change policy-makers and practitioners identify. Next the data is used to investigate three pertinent 
dimensions of such forums. First, at what scales are these effective forums primarily perceived to operate (Table 1)? This enables examination of the multilateralism - minilateralism discussion. In terms of scale, responses were grouped into the following categories: multilateral forums, i.e. forums with near universal state membership, subdivided into UN or other Intergovernmental agencies (UN IGO and Other IGO) - please note that this is different from the more common definition of multilateralism as collaboration between three or more states; minilateral forums, i.e. groupings with select state membership, such as climate and economic clubs like the Major Emitter Forum and G8; Regional forums such as the EU and the African Union; Bilateral, National, and Local forums. The No scale category refers to responses where scale cannot be discerned, such as businesses and forests.

Second, what issue-areas do these forums primarily address? This illuminates whether effective climate change responses require collaboration outside the climate realm, i.e. do respondents acknowledge other climate, environmental, economic or social forums (Table 2)? Five categories of issue-areas for the forums outside the UNFCCC were formed: climate, environmental forums, economic forums, social forums and general forums. Three subcategories of environmental forums are also presented here: atmosphere, biodiversity, and other environmental issues. The Not spec category refers to those forums where issue-area cannot be discerned, such as communities and high-level political forums.

Third, are these forums led primarily by governments or are other actors more frequently involved? In order to examine who is leading these forums, data was categorized according to: state-led forums, IGO-led forums, hybrid forums (i.e. a mix of state and non-state actors), non-state-led forums, and Not specified (Supplementary Table 1). These patterns are compared across the six world geographical regions and between governmental and non-governmental respondents.

To detect trends over time, values are reported for the All governmental and All NGO categories in tables 1-2 and Supplementary Table 1. We compensated for variations in world region sample sizes at the two COPs by multiplying COP-19 responses with the shares of the COP-20 sample.

\section{References}

${ }^{25}$ Betzold, C. Responsiveness or influence? Whom to lobby in international climate change negotiations. International Negotiation 19, 35-61, (2014).

${ }^{26}$ Böhmelt, T., Koubi, V. \& Bernauer, T. Civil society participation in global governance: Insights from climate politics. European Journal of Political Research 53, 18-36, (2014).

${ }^{27}$ Parker, C., Karlsson, C., Hjerpe, M. \& Linnér, B-O. Fragmented climate change leadership: making sense of the ambiguous outcome of COP-15. Environmental Politics 21(2), 268-286, (2012).

${ }^{28}$ Nasiritousi, N., Hjerpe, M. \& Buhr, K. Pluralising climate change solutions? Views held and voiced by participants at the international climate change negotiations. Ecological Economics 105, 177-184, (2014).

${ }^{29}$ Linnér, B-O. \& Pahuja, N. A Registry for Nationally Appropriate Mitigation Actions: Goals, Outcomes and Institutional Requisites. Ambio 41(S1), 56-67, (2012). 
${ }^{30}$ Friman, M. \& Hjerpe, M. Agreement, significance, and understandings of historical responsibility in climate change negotiations. Climate Policy. doi:10.1080/14693062.2014.916598, (In press).

${ }^{31}$ Nasiritousi, N., Hjerpe, M. \& Linnér, B-O. The roles of non-state actors in climate change governance: understanding agency through governance profiles. International Environmental Agreements: Politics, Law and Economics, doi:10.1007/s10784-014-9243-8, (2014).

${ }^{32}$ Buhr K., Roth, S. \& Stigson, P. Climate Change Politics through a Global Pledge-and-Review Regime: Positions among Negotiators and Stakeholders. Sustainability 6(2), 794-811, (2014).

${ }^{33}$ Buhr, K. \& Hjerpe, M. Expectations on corporate climate action under regulatory uncertainty. International Journal of Climate Change Strategies and Management 4(4), 403-419, (2012).

${ }^{34}$ UNFCCC. List of Participants, Conference of the Parties, Nineteenth Session, http://unfccc.int/resource/docs/2013/cop19/eng/inf04.pdf, (2013).

${ }^{35}$ UNFCCC. List of Participants, Conference of the Parties, Twentieth Session, http://unfccc.int/resource/docs/2014/cop20/eng/misc01p01.pdf, (2014).

${ }^{36}$ Hjerpe, M. \& Linnér, B-O. Functions of COP side-events in climate-change governance. Climate Policy 10, 167-180, (2010). 
Policy-makers' and practitioners' views on forums for effectively tackling climate change

Mattias Hjerpe and Naghmeh Nasiritousi

Centre for Climate Science and Policy Research, CSPR, and Department of Thematic Studies

- Environmental Change, Linköping University, Sweden.

Supplementary Table 1: Percentage of all COP19/20 respondents indicating state- versus non-state led forums divided into governmental and NGO representatives.

\begin{tabular}{|l|ccccc|}
\hline & State & IGO & Hybrid & $\begin{array}{c}\text { Non- } \\
\text { state }\end{array}$ & $\begin{array}{c}\text { Not } \\
\text { specified }\end{array}$ \\
\hline All government & $\mathbf{4 7}$ & $\mathbf{4 1}$ & $\mathbf{1 4}$ & $\mathbf{1 9}$ & $\mathbf{1 0}$ \\
COP-19* & 45 & 54 & 15 & 15 & 9 \\
COP-20 & 48 & 34 & 15 & 21 & 11 \\
Africa & 44 & 33 & 14 & 16 & 18 \\
Asia & 30 & 39 & 18 & 16 & 15 \\
Europe & 69 & 44 & 12 & 21 & 2 \\
North America & 74 & 32 & 21 & 5 & 11 \\
Oceania & 46 & 50 & 4 & 13 & 4 \\
S\&L America & 28 & 53 & 21 & 19 & 4 \\
\hline All NGO & $\mathbf{4 0}$ & $\mathbf{3 1}$ & $\mathbf{1 0}$ & $\mathbf{4 0}$ & $\mathbf{7}$ \\
COP-19* & 33 & 28 & 13 & 37 & 12 \\
COP-20 & 42 & 31 & 10 & 42 & 5 \\
Africa & 33 & 38 & 8 & 23 & 13 \\
Asia & 36 & 26 & 8 & 31 & 10 \\
Europe & 47 & 32 & 9 & 41 & 4 \\
North America & 46 & 30 & 10 & 46 & 5 \\
Oceania & 62 & 34 & 14 & 41 & 3 \\
S\&L America & 21 & 31 & 13 & 52 & 9 \\
\hline
\end{tabular}

NB! Respondents could indicate several fora and, consequently, the total percentages do not sum up to $100 \%$ (in each row of the table). * COP-19 values were compensated for variations in sample sizes in world regions using the regional governmental respondent shares of the COP-20 sample.

\section{Non-governmental (NGO) respondents' perceptions of other forums}

In terms of scale (Table 1), NGO representatives expressed relatively stable preferences across world geographical regions for multilateral, UN-led forums and more variability in the preferences for minilateral forums. This pattern was more pronounced among European and Oceanian NGO representatives and weaker among African and South and Latin American NGO representatives.

In terms of issue-areas (Table 2), NGO representatives indicate stronger preferences for social forums and weaker for environmental ones than government representatives and growing preferences for economic forums from COP-19 to COP-20. 
In terms of whether the identified forums are led by states, IGOs, non-state actors or hybrid arrangements (mix of state and non-state actors), unsurprisingly, NGO respondents overall mention non-state-led forums more often than government representatives (Supplementary Table 1). While they do so twice as frequently as the government representatives, this results in equally strong overall preferences for state- and non-state-led forums (40\%) and stronger than those for both IGO-led and hybrid forums. This is valid for African, Asian, European and North American NGO representatives. Preferences for state-led forums are stronger among Oceanian NGO representatives and weaker among South and Latin American NGO representatives. The latter express preferences for more direct involvement of people to take climate action. NGO representatives' preferences for non-state-led forums diverge substantially across geographical regions. North and South and Latin American NGO representatives' preferences for non-state-led forums are stronger and those expressed by African and Asian ones weaker. This may reflect the uneven pattern of non-state initiatives currently underway ${ }^{3}$. 